DOI: https://doi.org/10.15407/techned2018.04 $: \underline{037}$

\title{
GENERATOR OF HIGH-VOLTAGE NANOSECOND PULSES WITH REPETITION RATE MORE THAN 2000 PULSES PER SECOND FOR WATER PURIFICATION BY THE DISCHARGES IN GAS BUBBLES
}

$\quad$ Journal
Publisher
ISSN
Issue
Pages

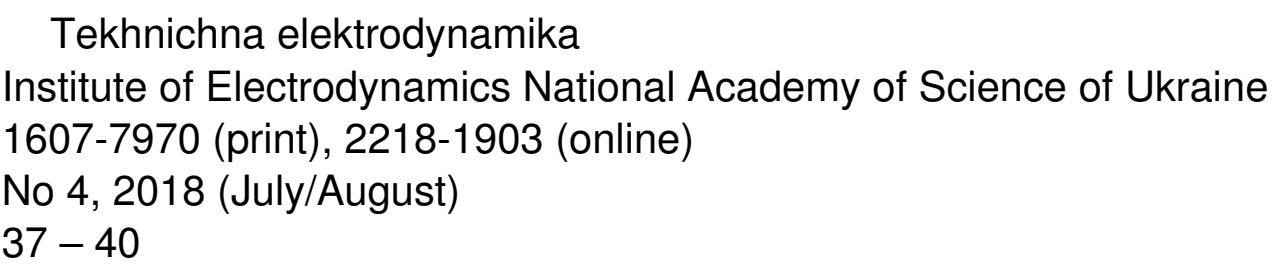

\author{
Authors \\ N.I. Boyko*, A.V. Makogon* \\ National Technical University «Kharkiv Polytechnic Institute», \\ Kyrpychova st., 2, Kharkiv, 61002, Ukraine, \\ e-mail: qnaboyg@gmail.com; boyko@kpi.kharkov.ua \\ * ORCID ID : http://orcid.org/0000-0002-1362-2867 \\ ** ORCID ID : http://orcid.org/0000-0002-3889-2601
}

\section{Abstract}

Purpose. Purpose of this work is to create generator of high-voltage nanosecond pulses capable of operating on a load in the form of a layer of water with gas bubbles at a pulse repetition rate of more than 2000 pulses per second, and experimentally investigate with its aid the characteristics of nanosecond discharges in gas bubbles for water purification. Met hodology

. Generator of nanosecond pulses was created on the basis of the Tesla transformer scheme. 
We used multi-gap spark discharger to peak the front of high-voltage pulses.

Results.

Characteristics of high-voltage nanosecond discharges in gas bubbles in water are experimentally studied using a nanosecond pulse generator. These discharges allowed reducing the concentration of ammonia by $37 \%$ in a solution of ammonium nitrate in water during its purification.

\section{Originality}

. Multi-gap spark discharger provides a pulse repetition rate of more than 2000 pulse/s. Load of the generator was layer of water with gas bubbles with characteristic dimensions of $1-4 \mathrm{~cm}$ above it in the reactor. Voltage pulses with amplitude up to $30 \mathrm{kV}$, current pulses with amplitude of up to $35 \mathrm{~A}$ with characteristic durations of $60 \mathrm{~ns}$ and front durations of $10 \mathrm{~ns}$ are obtained in load. Shape of the pulses is close to the two-exponential waveform with superimposed oscillations.

\section{Practical value}

. Nanosecond discharges obtained experimentally in gas bubbles in water with voltage amplitude of several tens of kilovolts and the amplitude of current pulses in discharges of tens and more amperes open the prospect of purification and microbiological disinfection of water with such discharges with reduced specific energy costs in comparison with known methods. References 9, figures 4.

Key words: generator, high - voltage nanosecond pulse, discharge into gas bubble, water purification, multi gap spark discharger, peaking capacitance, reactor.

Received: 05.03.2018

Accepted: 28.03.2018

Published:

\section{References}


1. Boyko N.I., Makogon A.V. Experimental Plant for Water Purification with the Help of Discharges in Gas Bubbles. Tekhnichna elektrodynamika. 2017. № 5. Pp. 89 - 95. DOI: https:/ /doi.org/10.15407/techned2017.05.089

(Rus)

2. Boyko N.I. Scientific bases for the creation of electric technological plants for high-voltage pulsed effects: The author's abstract of the dissertation ... doctor of technical sciences:

05.09.13. NTU KhPI. Kharkiv, 2003. 38 p. (Ukr)

3. Evdoshenko L.S. Improvement of high-voltage spark dischargers with alternating electric strength for electric technological plants: The author's abstract of the dissertation ... candidate of technical sciences: 05.09.13. NTU KhPI. Kharkiv, 2013. 21 p. (Ukr)

4. Foster J., Sommers Bradley S., Gucker S. N., Blankson I. M., and Adamovsky G. Perspectives on the Interaction of Plasmas with Liquid Water for Water Purification. IEEE Transactions on Plasma Science

. 2012. Vol. 40. No 5. Pp. 1311-1323. DOI:

https://doi.org/10.1109/TPS.2011.2180028

5. Gershman S., Mozgina O., Belkind A., Becker K., and Kunhardt E. Pulsed Electrical Discharge in Bubbled Water. Contributions to Plasma Physics. 2007. Vol. 46. No. 1-2. Pp. 1-7. DOI:

10.1002/ctpp.200710002 https://doi.org/

6. Hazmi A., Desmiarti Reni W., Eka P. \& Darwison. Removal of Microorganisms in Drinking Water using a Pulsed High Voltage. J. Eng. Technol. Sci. 2013. Vol. 45. No. 1. Pp. 1-8. DOI: $\underline{\mathrm{h}}$ ttps://doi.org/10.5614/j.eng.technol.sci.2013.45.1.1

7. Kebriaei M., Ketabi A. and Niasar Abolfazl H. Pulsed Corona Discharge, a New and Effective Technique for Water and Air Treatment. Biological Forum. 2015. No. 7(1). Pp. 1686-1692.

8. Malik Muhammad A., Ghaffar A. and Malik Salman A. Water purification by electrical discharges. Plasma Sources Sci. Technol. 2001. No. 10. Pp. 82-91. DOI: https://doi.org/10.10 88/0963-0252/10/1/311

9. Nazarenko O.B, Shubin E.G. Investigation of Electric Discharge Treatment of Water for Ammonium Nitrogen Removal. Environmental Physics Conference, Alexandria, Egypt, 18-22 Feb. 2006. Pp. 85-90.

$\underline{\text { PDF }}$ 